\title{
O CIBORGUE ENTRE A BIO-ARTE E A ARTE DISTURBATÓRIA
}

\author{
Jean Cardoso* \\ Centro Federal de Educação Tecnológica de Minas Gerais \\ Minas Gerais, BR
}

\section{Resumo}

A presença do ciborgue na contemporaneidade, como entendido pela bióloga e filósofa Donna Haraway em Antropologia do Ciborgue (2009), traz consigo um conjunto de signos que compõem nosso mundo. Dentre esses signos estão às operações transgênicas que o antropólogo e poeta Luís Quintais critica na obra Uma arte do degelo (2015) por meio do efeito performático da bio-arte. Porém, ao confrontarmos tal efeito com o conceito de arte disturbatória do filósofo Arthur Danto, presente na obra O descredenciamento filosófico da arte (2015), a ética oriunda da bio-arte como proposto por Quintais perde em vitalidade. Contudo, recorremos ao imaginário do escritor Fausto Fawcett na obra Favelost (2012) como forma de dialogar com os teóricos presentes nesta investigação a fim de se abrir perspectivas a novos mundos para o pós-humano.

Palavras-chave: Ciborgue; Bio-arte; Arte Disturbatória; Performance; Ficção.

\section{THE CYBORG BETWEEN BIO-ART AND DISTURBATORY ART}

\begin{abstract}
The presence of the cyborg in contemporary times, as understood by the biologist and philosopher Donna Haraway in Antropologia do Ciborgue (2009), brings with it a set of signs that make up our world. Among these signs are transgender operations that the anthropologist and poet Luís Quintais criticizes in the work Uma arte do degelo (2015) by means of the performative effect of bio-art. However, when we compare this effect with the concept of disturbatory art of the philosopher Arthur Danto, present in the work The Philosophical Disenfranchisement of Art (1986), the ethics of bio-art as proposed by Quintais weakens in vitality. However, this article resorts to imaginary of the writer Fausto Fawcett in the work Favelost (2012) as way of dialoguing with the theorists present in this research in order to open perspectives to new worlds for the post-human.
\end{abstract}

Key-words: Cyborg; Bio-art; Disturbatory art; Performance; Fiction.

A precessão dos signos que povoam o mundo do pós-humano faz com que meçamos nossa humanidade cada vez mais por meio dessa nova forma de ser. Antes mesmo da efetiva incorporação das próteses, nosso imaginário é seduzido com promessas de vida abundante em um futuro que a publicidade repetidas vezes diz já ter chegado. Este é o contexto pós-humano em que o escritor Hari Kunzru (2009, p.23), referindo-se aos ensinamentos de Donna Haraway, nos diz o quanto nos identificamos ao conceito de ciborgue; ele está "onde quer que haja um carro, um telefone ou um gravador de vídeo. Ser um ciborgue não tem a ver com quantos bits de silício temos sob nossa pele ou com quantas próteses nosso corpo contém."

Quando criticamente discutimos os graus de adoção ou recusa dessa nova forma de ser humano transitamos entre as fronteiras da natureza e cultura que outrora se encontravam razoavelmente estáveis. A dificuldade de ocupar este não-lugar é grande e Haraway reconhece isto:

Os recursos analíticos desenvolvidos pelas pessoas progressistas insistem no argumento de que a técnica envolve, necessariamente, dominação;

*Graduado em Filosofia pela UFMG em 2001. Especialização em Educação Ambiental em 2007 pela UEMG. Mestrado em Estudos de Linguagens pelo CEFETMG em. Doutorando em Estudos em Linguagens pelo CEFET-MG. Seu e-mail é jeanamerico@bol.com.br 
como resposta, elas apelam em favor de um imaginário corpo orgânico que possa organizar nossa resistência. (2009, p.45)

Mas ela insiste que esta dificuldade pode nos ajudar a não enxergar o mundo dos ciborgues apenas como ameaça, nem tampouco, apenas como libertação. Para Haraway (2009, p.36), "o ciborgue é uma criatura de realidade social e também uma criatura de ficção." Daí, a ficção pode ser entendida como uma alternativa para se pensar a sociedade do ciborgue, permitindo inclusive que recorramos à produção literária ficcional nacional para se pensar a pós-humanidade à brasileira.

Como forma de manter viva a possibilidade de ficcionar a realidade, sem que aceitemos acriticamente a verdade inerente aos signos do pós-humano, ordenada segundo a força imperativa da racionalidade técnica e do capital em nossa sociedade, propomos investigarmos como o efeito de performance está presente na bio -arte, uma arte tipicamente pós-humana. A bio-arte, tal como entendida pelo antropólogo e poeta Luís Quintais na obra Uma arte do degelo (2015), tende a suprimir por meio do próprio efeito de performance a ideia de representação como forma de se pensar o humano num contexto de indistinção entre natureza e cultura. Neste sentido, a crítica do filósofo estadunidense Arthur Danto ao efeito de performance na obra $O$ descredenciamento filosófico da arte (2015), por meio de seu conceito de arte e disturbação, será estendida nesta investigação à bio-arte para uma análise do que pode significar uma arte que se identifica totalmente com a vida.

A bio-arte é uma expressão artística que recorre às formas de vida como substrato para a criação de seus trabalhos. Seus procedimentos abarcam tanto os processos naturais quanto os laboratoriais da engenharia genética. Luís Quintais, entretanto, ao tratar desta manifestação artística em sua obra Uma arte do degelo (2015), aponta para uma espécie de continuidade entre os polos naturais e laboratoriais da bio-arte, como poderia demonstrar o nível de interferência na natureza no procedimento de artistas como Eduardo Kac e Marta de Menezes, analisados na referida obra.

Quintais justifica o casamento entre o artista e o laboratório por entender que é papel do artista rediscutir sua relação com a ciência, principalmente quando esta se converte em tecnociência. Por esse motivo o artista assume o procedimento laboratorial como forma de expressão crítica:

\begin{abstract}
A obra de arte na era da reprodutibilidade biotech resulta assim em um desvio de práticas de laboratório mais ou menos comuns no domínio das bio-tecno-ciências. Os artistas que desenvolvem este tipo de prática fazem-no em contexto laboratorial e em conjunto com os tecno-cientistas de laboratório habituados a seus procedimentos e protocolos. (QUINTAIS, 2015, p.12)
\end{abstract}

A crítica à "reprodutibilidade biotech" seria então uma espécie de ato estético e político do artista, feito a partir do interior das próprias "bio-tecno-ciências". Ou seja, é assumindo as ferramentas e as operações da biotecnologia que o artista vai evidenciar o conjunto de forças que determinam a reprodutibilidade dos eventos biotecnológicos. A bio-arte para Quintais seria uma maneira do artista "perfomatizar o conhecimento" (Idem, 2015, p.12) fazendo um híbrido entre o seu procedimento criativo e o procedimento duro do tecno-cientista.

A produção tecno-científica ao se aproximar da produção de vida via reorganização genética nos remete à problematização do que é o humano, dentro de um cenário em que natureza e cultura se atravessam. O técnico-cientista preenche de determinações os códigos genéticos que se objetivam em matéria segundo uma expectativa que lhe é externa. As bases hidrogenadas do DNA seriam o substrato que antecede a intervenção do tecno-cientista, sua herança; assim como a reconfiguração destas bases em nível molecular seria a renovação que propõe o tecno-cientista. Desta forma, a natureza operaria conforme o binômio que define a cultura: herança e renovação. Quintais entende que os bio-artistas seriam responsáveis por refrear a declinação faústica ${ }^{1}$ dos bio-tecno-cientistas, colaborando com novas formas de reflexão sobre o presente e a natureza reconfigurada:

Assim, uma de suas acepções [do presente] seria a de um mundo onde esta reconfiguração se afiguraria de tal forma profunda que solicitaria formas 
generalizadas de reflexividade, formas essas que poderiam ser (e são) potenciadas pelas práticas artísticas dos bio-artistas. É certo que, neste cenário de transgressão tecnológica, as tonalidades utópicas depressa se tornam enfaticamente distópicas. $(2015$, p.22)

A crítica desconstrutiva que o filósofo Paul Virilio faz à arte transgência, ${ }^{2}$ assumida em Uma arte do degelo como dirigida a Eduardo Kac, é questionada por Quintais (2015, p.34) como forma de evidenciar que a própria crítica de Kac sobre seus trabalhos é capaz de promover uma reflexividade ética e política à influência mercantil nos procedimentos e resultados aparentemente "desinteressados, desapaixonados e humanamente necessários" das bio-tecno-ciências por torná-las públicas. Desta forma, evitaria-se que "a dimensão performativa da tecno-ciência é [fosse] apagada do espaço público" (QUINTAIS, 2015, p.36). A crítica que Virilio faz à tecnociência, de que cada procedimento técnico, contém já subtendido seu acidente, é adaptada por Quintais de forma a demonstrar que a arte transgênica em seu trabalho performativo é capaz de dotar o acidente de um espaço de indeterminação que a tecno-ciência não suporta:

Acresce que é notório que a arte transgênica se instala num território de ambiguidade semântica e de maximização da inquietação pública que torna a dúvida instrumental e produtiva para as suas práticas artísticas e reflexivas. Este território é sem dúvida o território de toda arte, mas aqui, e dada à severidade das propostas que se encontram em jogo quando pensamos nos usos que poderão ser dados às bio-tecno-ciências, a ambiguidade e a inquietação tornam-se especialmente operativas e urgentes para muitos, Kac não foge a isso. $(2015$, p.34)

A tecno-ciência procura determinar a ambiguidade dos experimentos transgênicos naquilo que transita entre o orgânico e o não orgânico, entre a natureza e a cultura. Quintais defende que a publicização performativa/reflexiva da bio-arte seja a garantia da dimensão ética que acompanha os procedimentos da própria bio -arte, logo, também, das bio-tecno-ciências. Mas, até que ponto é possível resguardar algum nível de aleatoriedade na intervenção do bio-artista na estrutura do DNA, se já de partida oferecemos um campo de atuação definido como o das bio-tecno-ciências? Quantas portas se abrem e quantas se fecham segundo este procedimento? O próprio campo técnico de atuação humana tende a limitar os procedimentos da bio-arte, mesmo sendo isto o que ela queira performatizar.

Embora Quintais (2015, p.30) aponte um descompasso teórico que existe entre pensadores que defendem o pós-humanismo juntamente à recusa da "definição heideggeriana do humano como essência que precede a técnica", sua expectativa com a bio-arte, talvez como forma de se negar esse descompasso, parece ainda consideravelmente associada à dimensão epistemológica unilateral da bio-tecno-ciência. Tal expectativa assume também o risco de que as intervenções do bio-artista convertamse em instrumentos de consumo para as massas, como a publicidade e a curiosidade, do que a rigor nenhuma manifestação artística está isenta, mas que na dinâmica associação performativa da bio-arte entre objeto, artista e público, tem esse risco aumentado.

Se nos detivermos numa ampliação da ideia de performance para aplicação à bio-arte, alguns entraves podem se colocar em relação à expectativa que Quintais deposita nesta manifestação artística. O conceito de arte disturbatória, como uma interpretação específica de certas características da performance, elaborado pelo filósofo da arte estadunidense Arthur Danto nos possibilita reavaliar a investida performática da bio-arte. Segundo Danto a disturbação seria:

O termo é pensado, naturalmente, para aludir à sua rima natural em inglês, já que a masturbação é uma atividade que concilia uma demarcação similar, na qual algumas imagens e fantasias têm efeitos externos - meras imagens carregadas culminam em orgasmos reais e induzem a uma redução real da tensão. E, em certo sentido, isso modela o que a arte da disturbação procura obter, produzir um espasmo existencial por meio da intervenção das imagens na vida. Mas o termo também é pensado para reter as conotações de distúrbio, porque essas várias artes, frequentemente em consequência de sua execução improvisatória e precária, portam certa ameaça, até mesmo prometem certo perigo, se comprometem com a realidade num modo que as artes mais entrincheiradas e suas descendentes perderam o poder de conseguir. (2015, p.157) 
A princípio, a bio-arte não responderia necessariamente pelo efeito de descarregar tensão da masturbação, já que, nesse sentido, Danto refere-se a performances que remetem a imagens pornográficas e religiosas tradicionais. Contudo, é possível imaginarmos que seres (objetos de arte) transgênicos possam ser erotizados, produzindo efeitos somáticos e psíquicos nos seus interventores. Mas, em relação ao aspecto de distúrbio provocado pela quebra de padrões sociais, científicos e artísticos, a bio-arte cumpre bem esta função performática disturbatória; "na arte disturbacional o artista não está se refugiando por trás das convenções: ele está abrindo um espaço que as convenções são concebidas para manter fechado" (DANTO, 2015, p.162). Este é o projeto que Quintais (2015, p.29) entende como compromisso ético da bio-arte; tirar das mãos dos técnocientistas e dos donos dos laboratórios o monopólio deste conhecimento, "uma vez a caixa de Pandora aberta há que aprender a viver com ela destampada."

O estranhamento performático das quimeras produzidas pela bio-arte instala-se na instantaneidade de seu procedimento ao reconciliar absolutamente arte, filosofia e vida. Os seres transgênicos são ao mesmo tempo composição artística, concepção filosófica e ser vivo. Não se trata, portanto, da pintura, da modelagem ou da projeção de uma quimera; a criação de seres na bio-arte está para além de uma representação perturbadora.

$\mathrm{O}$ fator de instabilidade provocado pela presença de transgênicos no meio ambiente parece pouco ameaçador para a população de forma geral, que assume posturas das mais diversas em relação a esta situação, ora a desconhecendo, ora a ignorando total ou parcialmente; ou até mesmo, como proposto por Kac, abrindo um espaço de aceitação para novos seres como é o caso da coelha transgênica Alba. Uma vez que a bio-arte, utilizando-se dos recursos da tecnociência consiga estabelecer novas perspectivas para a inclusão de novos seres em nosso meio, inclusive como forma de repor seres em extinção, parece ainda, este intuito, esbarrar em diversas linhas de pensamento científico ecológico que ressaltam o perigo que seria a propagação de transgênicos convertida em diminuição da diversidade biológica da natureza, agindo por autoprodução. $\mathrm{Ou}$ seja, corre-se o risco de que as performances da bio-ar- te convertam-se em pirotecnia e não consigam romper com a padronização de pensamento e de corpos determinada pelas forças da técnica e do capitalismo sobre os novos seres, agora também determinadas por um apelo estético. Aceitar o desafio deste perigo ecológico nos procedimentos e resultados tecno-científicos, ou crer acriticamente que a bio-arte consiga evidenciar tais procedimentos e resultados é uma forma de se mergulhar na falta de garantias que enfrenta o público quanto ao desconhecido do futuro nas artes performáticas de caráter disturbatório, pois Danto nos adverte de que:

\begin{abstract}
A aura de perigo, de risco, em todo caso, acompanha o estranho domínio dessa expressão artística e parte do experienciar é não saber o que acontecerá a nós, uma vez que o contrato que define nossos direitos como público é cancelado. (2015, p.162)
\end{abstract}

Vale ressaltar que os seres transgênicos também estão submetidos ao risco de vida e má formação, mesmo considerando-se os cuidados metodológicos de sua criação, já que a mutação genética opera segundo uma força indelineável.

Danto considera que a arte disturbatória é regressiva quanto à experiência artística por revesti-la novamente de magia ao aniquilar a distância entre artista, objeto e público. $\mathrm{O}$ objeto mesmo de arte não seria distinto da ideia que ele representa, tornando-se ele próprio elemento ritualístico de alteração da realidade. Para o público em geral, o desempenho do tecnocientista junto ao bio-artista no laboratório tem o aspecto de "caixa preta" e desempenha algo semelhante às práticas ritualísticas dos sacerdotes pagãos. Mesmo que em contexto diferente do da bio-arte, Danto (2015, p.164) revela-se crítico em relação a uma parcela de seres vivos tomarem o lugar de um todo: "qualquer um que acredite que zoológicos são educacionalmente motivados tem um subdesenvolvido sentido de magia". Neste caso vale o questionamento do quanto a coleção de seres transgênicos se converte no desejo de se tomar a natureza como um todo tendo um acesso direto a ela.

Ainda sobre a transposição da perspectiva performática da arte-transgênica em arte disturbatória, este ramo da bio-arte encontra, nas formas pré-trágicas da 
cultura grega da qual a arte disturbatória se apropria, um contraponto que permite avaliar sua proposta de fortalecer parâmetros éticos para os procedimentos tecnocientíficos e a convivência com seres transgênicos. Embora o bio-artista não coloque sua vida em risco eminente quando cria vida transgênica, o perecimento dessa vida, além do próprio ato de criação de vida, exige um alto grau de suspenção das interdições para que o cientista-artista-deus seja capaz de fundar uma realidade, assim como era feito nos rituais dionisíacos em que o deus literalmente se fazia presente junto à euforia orgiástica do público. Para Danto a artista disturbatória

almeja transformar o seu público em algo préteatral, num corpo que se une a ela numa relação mais mágica e transformacional do que permitem as convenções definidoras do teatro. E ela pretende conseguir isso por meio de alguma transformação de si própria, que consiste abandonar a atmosfera protetora e fortemente deslocadora da distância teatral e fazer contato com uma realidade. $(2015$, p.168)

A suspenção das interdições nos rituais pré-teatrais provoca um efeito de esconjuro entre os seus participantes, devido ao horror que é viver a existência em sua plenitude de realidade, tal como ela é na natureza para nós mortais, sem sentido, caótica. Esse efeito não parece ser intenção dos bio-artistas, e talvez a ausência deste fator faça perder a força crítica de seus trabalhos. O esconjuro seria uma espécie de garantia de que, assim que o trabalho do bio-artista-Criador fosse consumado, seus símbolos fossem despotencializados, de forma que pudéssemos reconhecer que a magia elucubrativa dos sinais do DNA não expressam a realidade em sua plenitude, tratando-se este evento de um exercício metafísico de tudo desejar saber, a fim de superar a materialidade da condição humana. Danto, na citação abaixo, faz um paralelo entre o sacerdote dos rituais primitivos e o trabalho da performance:

Eu não aprecio a arte disturbatória talvez porque eu esteja sempre fora dela e a vejo como patética e fútil. E, ainda assim, estou cônscio de que haja um inegável poder na concepção do artista como um tipo de sacerdote num ritual primitivo e como a própria arte como uma intervenção miraculosa.
E é difícil desprezar a coragem de um artista que toma para si essa temível missão. Nietzsche deve ter sentido essa coragem em Wagner e esperava que Bayreuth pudesse recriar as sublimidades pré-teatrais da Grécia e atingir elementos na psique sufocada pela razão. (2015 pp.121,122)

Os elementos miraculosos performáticos da bio -arte, segundo os critérios da arte disturbatória, no entendimento de Quintais (2015, pp. 41, 62), poderiam ser evidenciados por meio do "gesto técnico" do bio-artista, de "sua mão é assumidamente visível".

A visibilidade do gesto do bio-artista pode distrair nossos olhares para uma de suas mãos enquanto a outra desapercebidamente opera os sinais, os códigos, de sua "magia". Nesse contexto, os meios dessa operação, são tão, ou mais, significativos que seu resultado, ou seja, a manipulação (em sua dupla acepção) dos códigos de DNA é tão, ou mais, importante que a matéria dessa operação. No mundo do entretenimento, o impacto provocado pelos mágicos reveladores de truques é passageiro; o artista que prevalece é o que sacia a sede do público de se iludir. Não nos esqueçamos de que o trabalho de Eduardo Kac se origina com a Telepresença, até se desdobrar em seu trabalho de arte transgênica, como nos mostra o próprio artista em sua obra Telepresença e bioarte (2009). Há, portanto, o risco de que a determinação humana sobre o rearranjamento dos códigos tome o lugar de primazia de nossa experiência sensível com o mundo, muitas vezes limitada por instituições como as capitalistas e religiosas. Saímos da materialidade do sensível como motivo de irrupção de produção de nossa inteligibilidade para seu reverso, na bio-arte. Perdemos em intuição, como uma condição de passagem entre o indeterminado obscuro e as determinações racionais.

O "além homem" de Nietzsche, que na abertura da obra Uma arte do degelo (2015) encarna o espírito do touro enfurecido, rompedor das estruturas conservadoras, na citação que Quintais faz da fala de Zaratustra em Das antigas e das novas tábuas, não se separa da aliança entre vida e arte que Nietzsche propõe por meio da continuidade entre os espíritos dionisíaco e apolíneo em O nascimento da tragédia (1996). O distanciamento que Danto pede entre a experiência artística e a filosofia que dela resulta, por meio da crítica disturbatória à 
performance, reforça a ideia de uma continuidade entre vida e arte, não sua identidade como defende a arte transgênica sob o olhar de Quintais. Este, mesmo após questionar em consonância à Kac, as práticas laboratoriais das empresas, propõe um acerto de percurso ao invés de criar outro caminho. A nossa relação com a natureza já foi regida pelo mito e pela ciência, não poderia ser agora regida por uma experiência sensorial artística como forma de recusa de uma racionalidade fechada em si mesma?

O questionamento sobre a medida da determinação humana sobre a natureza pela bio-arte tende a apagar a natureza como outro, dificultando a percepção de uma vida que é maior que a vida humana, da vontade que opera na natureza. A contraposição à expressão divina, "dominai sobre a natureza", do Gênesis não significaria uma forma de manutenção de uma vontade cega, inconsciente, pré-subjetiva, que existe em nós, quando associada à definição heideggeriana do humano como essência que precede a técnica? Não há no "dominai", mesmo que aparentemente despido de sua força religiosa pela ciência moderna, uma expressão de horror ao desconhecido, um desejo de transcender a condição humana dentro de sua própria imanência?

A presença deste desejo de transcendência pode revelar que mesmo após herdarmos da modernidade a secularização das instituições, no íntimo do indivíduo pós-moderno, pós-humano, sobrevive nele uma submissão ao efeito mágico/performático da bio-arte assim como ocorria, e ainda ocorre, em relação à liturgia religiosa. O sociólogo português Hermínio Martins (2012, p.18), por meio do conceito de gnosticismo tecnológico nos permite compreender melhor este contexto:

Todavia, pela expressão superficialmente paradoxal 'gnosticismo tecnológico' quer-se significar o casamento das realizações, projetos e aspirações tecnológicos com os sonhos caracteristicamente gnósticos de se transcender radicalmente a condição humana (e não simplesmente de a melhorar e habilitar os seres humanos a triunfarem sobre as forças naturais e hostis). Ultrapassar os parâmetros básicos da condição humana- a sua finitude, contingência, mortalidade, corporalidade, animalidade, limitação existencial - aparece como uma motivação e até como uma das legitimações da tecnociência contemporânea, pelo menos em algumas áreas.

Este "sonho gnóstico de transcender a condição humana”, expressão de verdade revelada no âmbito metafísico religioso, sofre um duro golpe com a morte de deus $^{3}$, mas não morre com ele. O limbo no qual vagavam as consciências niilistas que preferiam crer num deus cristão sem potência, nadificado, vazio, encontrou no gnosticismo tecnológico uma condição de paz e esperança para seu espírito. Neste sentido, a maquinaria moderna que foi considerada por Haraway (2009, p.43) "um deus irreverente e ascendente, arremedando a ubiquidade e a espiritualidade do Pai", sobrevive também na tecnociência contemporânea.

A estratégia pós-modernista de se tomar a obra, de natureza hermenêutica, como texto, opostamente aberto as colaborações interpretativas do meio, é o que permite tanto a Danto como a Haraway buscarem nas manifestações artísticas formas de se pensar o hibridismo que caracteriza essas manifestações, cuja teoria da referencialidade não suporta. Danto usa essa concepção de texto quando investiga a relação entre filosofia e literatura como nos mostra a citação seguinte:

Sinto que, se o conceito de texto se tornasse tão
central na filosofia analítica como tem sido o de
sentença desde que Frege lhe concedeu primazia,
ou como o termo tem sido desde Aristóteles, um
vasto mundo de pesquisa filosófica teria se aberto.
Porque o conceito de texto é consideravelmente
mais amplo do que apenas o texto literário. Ele se
aplica a composições musicais e a estruturas ar-
quitetônicas, formas de arte cuja referencialidade
tem estado ocasionalmente em questão, e a per-
sonalidades, vidas inteiras no sentido biográfico
do termo, a famílias, a povoados, culturas, coisas
para as quais a questão da referencialidade dificil-
mente tem sido levantada. (2015, p.187)

Haraway, por sua vez, não se limita ao texto como operador de manifestações artísticas e culturais, e engloba outras totalidades orgânicas, como ela mesma descreve abaixo:

É certamente verdadeiro que as estratégias pósmodernistas, tal como o meu mito do ciborgue, 
subvertem uma quantidade imensa de totalidades orgânicas (por exemplo, o poema, a cultura primitiva, o organismo biológico). Em suma, a certeza daquilo que conta como natureza - uma fonte de insight e uma promessa de inocência - é abalada, provavelmente de forma fatal. Perde-se a autoria/autoridade transcendente da interpretação e com ela a ontologia que fundamentava a epistemologia “ocidental". (2009, p.42)

Este encontro barthesiano entre Danto e Haraway evidencia a porosidade das fronteiras entre natureza $e$ cultura típica da arte transgênica, cuja referencialidade não encontra estatuto estável para fundamentar o ser segundo a tradição da epistemologia ocidental.

Ao retomarmos a concepção de Haraway (2009, p.36) de que "o ciborgue é uma matéria de ficção e também de experiência vivida", demarcamos a ficção como o meio pelo qual autor e intérprete se encontram, fazendo do compartilhamento do texto, um signo fragmentado do real, que assume o lugar da própria realidade. Portanto, a investida crítica sobre a bio-arte naquilo que tange seu papel performativo não pode redimir-se de uma mirada intencionalmente distópica para o futuro.

Numa perspectiva de aproximação entre a bio-arte e body art, ${ }^{4}$ em que horizontes perturbadores podem ser vislumbrados a partir de associação entre ficções como Blade Runner (1982) e Crash: estranhos prazeres (2004), por exemplo, podemos imaginar para nossa realidade nacional uma profusão de laboratórios de engenharia genética de fundo de quintal prestando um serviço nano tecnológico para estetas narcisistas, como descreve o escritor carioca Fausto Fawcett em Favelost (2012).

Na cidade híbrida Rio Paulo de Janeiro São, também conhecida como Favelost, concebida por Fawcett na referida obra como consequência de conurbação entre Rio de Janeiro e São Paulo, transitam ciborgues (num sentido bem superlativo à concepção de Haraway sobre o termo) movidos pelas promessas sedutoras que as corporações de Favelost fazem a quem carrega um sentimento de falta, num plano existencial. Ávidos por um estilo de vida acelerado, como se vive em jogos de realidade virtual ou em reality shows, o que Fawcett (2012, p.46) chama de "vida-game", se entregam a qualquer excentricidade estimulante de última geração, como a incorporação de "aplicativos cutâneos e neurodispositivos", por exemplo, para não pararem e se perguntarem pela condição de ser, e daí entrar em estado de paralisia "hamlética". Estado terminal que encontra nas mãos de "capatazes de humanistas" o extermínio frente à súplica: "me tire deste estado sólido, me tire deste estado sólido!" (FAWCETT, 2012, p.43)

Quem vive a "vida-game" de Favelost são os avatares das pessoas que se sobressaem a elas; troca-se de nome, de forma, de profissão na medida em que se deseja se revestir de outro personagem. O efeito performático que une o personagem ao ser na vida de quem transita em Favelost é calculado por suas corporações mercantis de forma a não ser mais possível distinguir traços de singularidade em seus indivíduos. A insistente representação de um papel predeterminado pelas corporações é o que define, sempre de maneira transitória, as pessoas de Favelost. Transitoriedade que se transforma em signo desta sociedade que não reconhece fronteiras entre natureza e cultura quando promove a bricolagem de tudo com tudo, entre o orgânico e o inorgânico, como nos diz Fawcett (2012, p.15): "Por todo canto da Mancha Urbana, ouve-se o sussurro de Lavoisier turbinado num trocadilho: 'nada se perde, nada se cria, tudo se Transformer."

Tudo o que é produzido em Favelost é material de pesquisa para empresas como a Nanocréu, inclusive o corpo liquefeito de quem passa pelo estado "hamlético". Esta passagem não leva aos céus, mas não deixa de revelar uma fé numa espécie de expurgo que promove esta liquefação. A filosofia em Favelost ajudou a retirar a fé da religião, seu caráter de transcendência e de amor incondicional, deslocando tal poder para a ciência, como nos diz Fawcett (2012, p.46) ao comparar estas três instituições: "a ciência como uma fera solta, a religião como uma besta trôpega, a filosofia como uma cafetina de jurisprudência.”

Ao contrário do que possam sugerir as ficções que têm como um de seus temas a reprodução assexuada, a distopia Favelost, ou como nomeia Fawcett, a "disputopia" Favelost, traz para o cenário ficcional, sob o signo do excesso que também transpassa toda a obra, a potencialização do sexo por meio de próteses mecânicas, químicas e imagéticas das mais variadas formas, fazen- 
do dessa nova roupagem da sensualidade atribuída aos habitantes dos trópicos um dos elementos de interesse de pesquisa antropológica sobre Favelost, que é objeto de pesquisa dentro da própria obra. $\mathrm{O}$ sucesso e o interesse social-antropológico de Favelost estão ligados à inversão de uma marca de nossa brasilidade, "a mitologia do complexo de vira-lata" (FAWCETT, 2012, p.28), que Fawcett (2012, p.29) faz questão de reforçar positivamente como capacidade adaptativa de vida que essa mistura de raças caninas consegue, transferindo-a para a sociedade humana, brasileira de Favelost: "o vira-lata é que é complexo."

Promover um diálogo entre teorias e as produções ficcionais de artistas e pensadores de diferentes espaços, mas que não são diametralmente opostos, potencializa o resultado da comparação entre ambos, pois caso fosse evidente a divergência entre eles, a afirmação de um corresponderia imediatamente à negação do outro. Disto resultaria um exercício de pensamento de uma via única; por outra maneira, posições que ora se assemelham, ora se dissociam, produzem uma dissonância que instiga nosso espírito.

Assim, considerando-se os habitantes/transeuntes de Favelost como representantes ciborgues do pós-humanismo, não encontramos na fala de Fawcett traços de prejulgamentos desta condição humana, como também não encontramos em Haraway. Fawcett fala sobre as incertezas ontológicas colocadas pela tecnociência em seus procedimentos transgênicos como algo dado. $\mathrm{O}$ recurso à linguagem escrita que diferencia a ficção de Fawcett da bio-arte, esta, como entendida por Quintais, demarca uma distância necessária para que o meio pelo qual a filosofia de uma arte se expresse não se identifique plenamente com os sinais e os códigos dessa arte. Neste sentido é que a crítica de Quintais à arte transgênica tem mais a aparência de uma apologia que propriamente de uma crítica. Por fim, o risco maior que corremos é que discursos apologéticos aos procedimentos transgênicos da tecnociência não encontrem oposição nas artes, convertendo-se, então, numa unidade discursiva religiosa sustentada pela crença. Não criando outros mundos possíveis, como a ficção nos permite criar, tenderemos a buscar nos signos e nos objetos das sociedades distópicas pequenos ciclos de transcendência como forma de superar um corpo eternamente ultrapassado, como ocorre com os personagens de Favelost.

\section{Notas}

1. "A corrente fáustica enxerga na tecnociência a possibilidade de transcender a condição humana" (SIBILIA, 2002, p. 13), posição antagônica aos prometeístas que "consideram que há limites ao que pode ser conhecido feito e criado" (SIBILIA, 2002, p. 45).

2. Um exemplo da arte transgênica é a performance GFP Bunny: Kac deu o nome de Alba à coelhinha albina que foi alterada geneticamente por ele com a inclusão de uma proteína animal que realça a cor verde fluorescente, conforme descrito em seu site http:// www.ekac.org/gfpbunny.html

3. Assim como entendida por Nietzsche, principalmente em sua obra Assim falou Zaratustra (1998).

4. A body art, ou arte do corpo, designa uma vertente da arte contemporânea que toma o corpo como meio de expressão e/ou matéria para a realização dos trabalhos, associando-se frequentemente a happening e performance. Não se trata de produzir novas representações sobre o corpo - encontráveis no decorrer de toda a história da arte -, mas de tomar o corpo do artista como suporte para realizar intervenções, de modo geral, associadas à violência, à dor e ao esforço físico. [...] Tatuagens, ferimentos, atos repetidos, deformações, escarificações, travestimentos são feitos ora em local privado (e divulgados por meio de filmes ou fotografias), ora em público, o que indica o caráter frequentemente teatral da arte do corpo. Bruce Nauman (1941) exprime o espírito motivador dos trabalhos, quando afirma, em 1970: "Quero usar o meu corpo como material e manipulá-lo”. Disponível em: http://enciclopedia.itaucultural.org.br/termo3177/ body-art Acessado em: 11/08/16

\section{Referências}

DANTO, Arthur Coleman; GILMORE, Jonathan; DUARTE, Rodrigo A. de Paiva. O descredenciamento filosófico da arte. Belo Horizonte: Autêntica, 2015.

FAWCETTI, Fausto. Favelost. São Paulo: Martins Fontes, 2012.

KAC, Eduardo. Telepresença e bioarte. São Paulo: Edusp, 2009.

Rabbit Remix. Disponível em: http://www.ekac. org/gfpbunny.html. Acessado em: 14/11/16

KUNZRU, Hari.; HARAWAY, Donna Jeanne; SILVA, Tomaz Tadeu da. Antropologia do ciborgue: as vertigens do pós-humano. Belo Horizonte: Autêntica, 2009. 
MARTINS, Hermínio. Experimentum Humanum: civilização tecnológica e condição humana. Belo Horizonte: Fino Traço, 2012.

NIETZSCHE, Friedrich. Assim falou Zaratustra: um livro para todos e para ninguém. 9. ed. Rio de Janeiro: Bertrand Brasil, 1998.

O nascimento da tragedia, ou, Helenismo e pessimismo. São Paulo: Companhia das Letras, 1996.

QUINTAIS, Luis. Uma arte do degelo. Lajes do Pico: Companhia das Ilhas, 2015.

SIBILIA, Paula. O homem pós-orgânico: corpo, subjetividade e tecnologias digitais. Rio de Janeiro: Relume Dumará, 2002.

\section{Audiovisuais}

Blade Runner. (EUA/Honk Kong). Direção: Ridley Scott. Ano de produção: 1982.

Crash: estranhos prazeres. (Grã-Bretanha, Canadá). Direção: David Cronenberg. Ano de produção: 2004.

Recebido em: 14/11/2016

Aceito em: 17/02/2017 